\title{
Programs to address child marriage: Framing the problem
}

\section{Sajeda Amin}

Population Council

Follow this and additional works at: https://knowledgecommons.popcouncil.org/departments_sbsr-pgy

Part of the Demography, Population, and Ecology Commons, Family, Life Course, and Society Commons, Gender and Sexuality Commons, and the International Public Health Commons How does access to this work benefit you? Let us know!

\section{Recommended Citation}

Amin, Sajeda. 2011. "Programs to address child marriage: Framing the problem," Promoting Healthy, Safe, and Productive Transitions to Adulthood Brief no. 14. New York: Population Council. 


\section{Programs to address child marriage: Framing the problem}

\section{Prepared by Sajeda Amin}

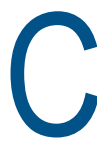
hild marriage violates girls' human rights and adversely affects their health and well-being. While age at marriage is increasing in most regions of the developing world, early marriage persists for large populations. Worldwide, it is estimated that more than one out of three women aged 20-24 were married before age 18, and one out of seven were married before age 15 (Population Council analysis of 2006 DHS data). There is great variation in child marriage practices across and within regions and between ethnic and religious groups. The highest proportions of child brides are typically found in West Africa and South Asia (see Table 1 for some regional hotspots of child marriage).

Eradicating child marriage has long been on the agenda of the United Nations and of individual countries. Indeed, all countries where child marriage occurs are signatories to international charters and covenants that discourage the practice. International human rights instruments, including the Universal Declaration of Human Rights (1948), the United Nations (UN) Convention on the Elimination of All Forms of Discrimination against Women (1979), the UN Convention on the Rights of the Child (1989), and the African Charter on the Rights and Welfare of the Child (1990), provide four main protections against child marriage:

- Requiring that intending parties exercise "free and full consent" in the marriage decision;

- Setting the minimum age of marriage at 18 , the upper limit of childhood as defined by the Convention on the Rights of the Child;

- Calling on states to ban "harmful practices," including child marriage; and

- Entitling children to special protections, including the right to express their views freely in all matters regarding their welfare; the right to education on the basis of equal opportunity; the right
TABLE 1 Percentage of women aged 20-24 who were married by age 15 and age 18, by geographical area

\begin{tabular}{lccc} 
Area & $\begin{array}{c}\text { Married } \\
\text { by } 15\end{array}$ & $\begin{array}{c}\text { Married } \\
\text { by } 18\end{array}$ & $\begin{array}{c}\text { Median age } \\
\text { at marriage }\end{array}$ \\
\hline Rajshahi, Bangladesh & 45 & 82 & 15 \\
Amhara, Ethiopia & 48 & 74 & 17 \\
Bihar, India & 18 & 60 & 18 \\
Rural Guatemala & 13 & 53 & 19 \\
Sahel, Burkina Faso & 19 & 87 & 17 \\
Northwestern Nigeria & 35 & 76 & 17 \\
\hline
\end{tabular}

Source: Population Council. 2011.

to protection from all forms of physical or mental violence, injury or abuse, maltreatment or exploitation; and the right to health and access to health services.

Despite these agreements, marriage before age 18-often without the young bride's consent-persists. A number of underlying factors help perpetuate early marriage: traditional gender norms, the high value placed upon female virginity, parental concerns surrounding premarital sex and pregnancy, dowry pressures, the perception that marriage provides protection from HIV and other sexually transmitted infections, and the desire to secure social, economic, or political alliances. Poverty also plays a major role. An extremely poor family may calculate that the husband's family will be better able to provide for their daughter, or the economic gains incurred through her marriage may be part of the family's survival strategy.

Research suggests that one way in which these factors coalesce is around girls' educational and economic opportunities. For example, the 
association between child marriage and low levels of schooling is consistently strong across all regions of the developing world. Women with three or fewer years of schooling are significantly more likely to have married early than are those with eight or more years of schooling (Mensch 2005). Being pulled out of school is less likely to be a consequence of early marriage; more often the same underlying conditions that drive the marriage timing decision—poverty, low status, and cultural norms—are responsible for the disinvestments in girls that limit their education (Mensch 2005). Furthermore, women's education and timing of marriage are intertwined across generations. A study in Bangladesh, for example, found that high levels of maternal education are associated with later marriage among daughters (Bates et al. 2007). In addition to schooling there is also a consistent association between early marriage and women's participation in the labor force before marriage. Findings from studies in Bangladesh show that young female garment workers marry significantly later than girls who do not work in the labor force (Amin et al. 1998).

These data suggest that educational and economic opportunities offer young women positive alternatives to early marriage that are acceptable to the family and to the community.

\section{Efforts to end child marriage}

The pervasiveness of child marriage requires multi-sectoral efforts to reframe the transition to marriage. Such a reframing includes three complementary goals:

- Delaying age at marriage;

- Making the marriage process consensual, safer, and more equitable; and

- Providing support for married girls (Haberland 2007).

Population Council researchers are seeking to prevent child marriage and to support married girls in several countries, including Bangladesh, Burkina Faso, Egypt, Ethiopia, Guatemala, India, Kenya, Nigeria, and Vietnam. These programs include expanding opportunities (education, livelihoods) for girls, especially those most at risk of early marriage, and working directly with gatekeepers (parents, boys/men, religious and community leaders) to remove barriers that prevent girls from accessing those opportunities. Such efforts may entail, for example, mass media messages and meetings with girls and gatekeepers to examine causes and consequences of early marriage, and/or to provide economic incentives to delay age at marriage.

Efforts to make the marriage process safer include voluntary counseling and testing for young women and men contemplating marriage, fostering more meaningful consent for girls in the marriage process, and fostering better-informed decisions by the bride's family. In some settings, addressing the economic factors, such as dowry and wedding costs, is key. These economic factors are of concern not just as causes of early marriage but as transactions that put girls at risk. For example, young women in Bangladesh who paid dowry are significantly more likely to report having been abused in the past year, and those who made dowry payments after marriage had an even greater likelihood of having been beaten than those who did not pay dowry (Suran et al. 2004).

Kishori Abhijan: Empowering girls with livelihood opportunities to delay marriage in Bangladesh

In Bangladesh 68 percent of girls over age 18 were married before their 18 th birthday, and one in three girls was married before the age of 15 . Although there is wide variation within the country, recent surveys suggest that around half of marriages involve a substantial dowry payment by the girl's family to the groom's family. The majority of marriages are arranged, and, although most girls report that their consent to marriage was sought in keeping with Islamic law, four out of five girls first met their husbands at the time of their wedding. These statistics are particularly baffling given the enormous gains that have been made in primary and secondary school enrollment of girls, the dramatic fertility decline among married women, and the vast expansion of micro-credit programs that cater primarily to women in rural areas. The continuation of early marriage and childbearing counters many of the gains in other sectors.

In an effort to change these patterns, the Population Council partnered with two Bangladeshi nongovernmental organizations (NGOs) to design and evaluate a large-scale program for adolescent girls. The program, known as Kishori Abhijan, sought to create opportunities that would inspire girls and their families to seek alternatives to early marriage. It provided a safe space for girls to meet, offered life-skills lessons, and, in some cases, provided access to livelihoods training, savings, and credit options. At the end of two years the program was successful in delaying marriage among the youngest and poorest girls. However, because girls still must pay dowry and older girls have to pay higher dowries, the average dowry paid among those who delayed marriage increased. Program leaders concluded that efforts to delay marriage are most beneficial when they expand economic opportunities for girls who see these new opportunities as meaningful alternatives to early marriage. These opportunities also help to defray the increasing costs of dowry that later marriage entails (Amin and Suran 2005a,b).

Berhane Hewan: Providing social support, education, and community awareness to delay early marriage in Amhara, Ethiopia In the Amhara region of Ethiopia, rates of child marriage are among the highest in the world. Half of all girls in Amhara are married before their 15th birthday. A Council study in Amhara and Addis Ababa found that for many young girls marriage may mean having sexual relations with a stranger: 95 percent of the girls surveyed did not know their husbands 
before marriage, and 85 percent were given no warning that they were about to be married. More than two-thirds of the married girls reported that they had not begun menstruating when they had sex for the first time (Erulkar et al. 2004).

Berhane Hewan (meaning "Light for Eve" in Amharic) is designed to assist girls by imparting the knowledge, skills, and resources to help them avoid child marriage. The program promotes functional literacy, life skills, and reproductive health education through groups of girls mobilized and led by a female mentor. In recognition of the economic motives for child marriage, material incentives were added to encourage families to allow their daughters to participate in girls' groups and to remain in school. The program was evaluated after 18 months. Findings suggest that, compared to levels of marriage at baseline, significantly fewer girls aged 10 to 14 are married (1.6\% project; $22.1 \%$ control), and significantly more girls in the younger age group are attending school (Erulkar and Muthengi 2009).

Abriendo Oportunidades: Building social, health, and economic resources to avoid early marriage in Guatemala

Guatemala is one of the most ethnically diverse countries in Latin America. It is also one of the poorest places in the Western Hemisphere, with poverty mostly concentrated among Mayan groups. Mayan girls are the most disadvantaged group in the country; early school dropout, early marriage, early and unwanted pregnancy, illiteracy, and limited life opportunities are all common features of their transition to adulthood.

Almost 40 percent of Mayan girls are married by age 18 .

In 2004 the Population Council began a project, Abriendo Oportunidades, designed to help girls make a successful transition to adulthood, including delaying marriage. Selected Mayan girls aged 16-20 participated in workshops on topics such as leadership, professional skills, public speaking, gender relations, and sexual and reproductive health. Girl leaders from local NGOs trained groups of younger girls (aged 10-15) in their communities to become mentors and taught them about self-esteem, life skills, and reproductive health. The project thus created "safe spaces" for Mayan girls and developed a sense of community among them. In addition to gaining valuable life skills, many girls were also able to better articulate plans for the future, such as furthering their education and opening their own businesses.

\section{Early marriage among the Hmong and Dao in Vietnam's Northern Uplands}

In Vietnam, a rapidly growing economy has benefited some groups, such as the majority Kinh population, while leaving others behind. Along with low education and poor health, early marriage is one of the defining characteristics of two of the most disadvantaged minority groups, the Hmong and the Dao.
Council researchers conducted a study in the poor and remote district of Vo Nhai in Thai Nguyen province, where the Dao and Hmong live with their Kinh neighbors. The Kinh, researchers learned, are likely to find opportunities for education and work outside the commune and tend to delay marriage. In contrast, over 65 percent of Hmong and Dao men and women aged 20-25 are married. Marriage is an important means of gaining economic independence from natal families and achieving recognition as an adult (Amin and Teerawichitchainan 2009).

\section{Areas for future work}

The great variation in marriage practices even within countries and communities suggests that our understanding of the marriage process remains limited. Little is known, for example, about consent to marriage, choice of spouse, familiarity with the selected spouse, and marital transactions. There is some evidence of growing agency among young women with regard to the marriage process, perhaps associated with the decline in early marriage. We hypothesize that these characteristics of marriage interact with poverty and female autonomy in the groom's family and the community to affect girls' and women's reproductive and sexual health and well-being.

Future programs and research must seek to clarify and address the pressure on families to marry off their daughters early; examine whether and how marriage-or specific components of the marriage process (such as consent, dowry, age at marriage)-disempower women in their intimate relations and place them at risk for adverse reproductive and health outcomes; and test how these effects may be ameliorated and the transition to marriage made safer. For example, can the right to consent be made more relevant in the context of girls' lives in terms of choosing when and whom to marry? And how is meaningful consent supported by providing alternatives to early marriage in settings where few or no alternatives traditionally existed?

The Council's research demonstrates that successful programs for girls are based on a clear understanding of the local cultural and economic context. Such programs also seek to expand opportunities for girls and limit the constraints to economic empowerment that compel girls and their families to choose early marriage and childbearing.

\section{References and related publications}

Amin, Sajeda. 2011. "Empowering adolescent girls in rural Bangladesh: Kishori Abhijan," Promoting Healthy, Safe, and Productive Transitions to Adulthood Brief no. 13. New York: Population Council.

Amin, Sajeda and Ashish Bajracharya. 2011. "Costs of Marriage - Marriage Transactions in the Developing World," Promoting Healthy, Safe, and Productive Transitions to Adulthood Brief no. 37. New York: Population Council. Amin, Sajeda and Bussarawan Teerawichitchainan. 2009. "Ethnic Fertility Differentials in Vietnam and Their Proximate Determinants." Population Council 
Poverty, Gender and Youth Division Working Paper 18. New York: Population Council.

Amin, Sajeda. 2006. "The implications of trade liberalization for working women's marriage: Case studies of Bangladesh, Egypt and Vietnam," in Caren Grown, Elissa Braunstein, and Anju Malhotra (eds.), Trading Women's Health and Rights? Trade Liberalization and Reproductive Health in Developing Economies. London: Zed Books, pp. 97-120.

Amin, Sajeda, Nasheeba Selim, and Nashid K. Waiz. 2006. "Causes and consequences of early marriage in Bangladesh: Background report for workshop on programs and policies to prevent early marriage." Dhaka: Population Council.

Amin, Sajeda. 2004. "Children and adolescents in Bangladesh: Definitions, rights and realities," in Dina M. Siddiqi (ed.), Human Rights in Bangladesh: 2003. Dhaka: Ain-o-Shalish Kendra.

Amin, Sajeda and Luciana Suran. 2005a. "Program efforts to delay marriage through improved opportunities: Some evidence from rural Bangladesh." Paper presented at the Annual Meeting of the Population Association of America, Philadelphia, 31 March-2 April.

Amin, Sajeda and Luciana Suran. 2005b. "The impact of marriage payments on leisure, housework and abuse of young wives: Some evidence from rural Bangladesh." Paper presented at the Annual Meeting of the Population Association of America, Philadelphia, 31 March-2 April.

Amin, Sajeda, Ian Diamond, Ruchira Naved, and Margaret Newby. 1998. "Transition to adulthood of female garment-factory workers in Bangladesh," Studies in Family Planning 29(2): 185-200.

Bates, Lisa, Joanna Maselko, and Sidney Ruth Schuler. 2007. "Women's education and the timing of marriage and childbearing in the next generation: Evidence from rural Bangladesh," Studies in Family Planning 38(2): 101-112.

Catino, Jennifer, Alejandra Colom and Marta Julia Ruiz. 2011. "Equipping Mayan girls to improve their lives," Promoting Healthy, Safe, and Productive Transitions to Adulthood Brief no. 5. New York: Population Council.

Clark, Shelley, Judith Bruce, and Annie Dude. 2006. "Protecting young women from HIVIAIDS: The case against child and adolescent marriage," International Family Planning Perspectives 32(2): 79-88.

Erulkar A.S. and Muthengi E. 2009. "Evaluation of Berhane Hewan: A program to delay child marriage in rural Ethiopia". Int Perspect Sex Reprod Health, 35(1):6-14

Erulkar, Annabel and Francis Ayuka. 2007. "Addressing early marriage in areas of high HIV prevalence: A program to delay marriage and support married girls in rural Nyanza, Kenya." New York: Population Council.

Erulkar, Annabel, and Tekle Ab Mekbib. 2007. "Reaching disadvantaged rural girls, creating social support, and discouraging child marriage in Amhara, Ethiopia." New York: Population Council.

Erulkar, Annabel, Tekle Ab Mekbib, Negussie Simie, and Tsehai Gulema. 2004. "The experience of adolescence in rural Amhara region, Ethiopia." Accra, Ghana: Population Council.

Glynn, J.R., M. Caraël, B. Auvert, M. Kahindo, J. Chege, R. Musonda, F. Kaona, A. Buvé, and the Study Group on Heterogeneity of HIV Epidemics in African
Cities. 2001. "Why do young women have a much higher prevalence of HIV than young men? A study in Kisumu, Kenya and Ndola, Zambia," AIDS 15(supplement 4): S51-S60.

Hallman, Kelly, Eva Roca, Marta Julia Ruiz, Jennifer Catino, Alejandra Colom,and Sandra Contreras Aprile. 2007. "For Mayan girls, safe spaces lead to social gains." New York: Population Council.

Haberland, Nicole 2007. "Supporting married girls: Calling attention to a neglected group," Transitions to Adulthood Brief No. 3. New York: Population Council.

Mensch, Barbara S. 2005. "The transition to marriage," in Growing Up Global: The Changing Transitions to Adulthood in Developing Countries. Panel on Transitions to Adulthood in Developing Countries, Cynthia B. Lloyd (ed.). Washington, DC: The National Academies Press, pp. 416-505.

Mensch, Barbara, Monica Grant, and Ann Blanc. 2005. "The changing context of sexual initiation in sub-Saharan Africa," paper presented at the meeting of the International Union for the Scientific Study of Population, Tours, 18-23 July.

Mensch, Barbara, Susheela Singh, and John Casterline. 2005. "Trends in the timing of first marriage among men and women in the developing world," in The Changing Transitions to Adulthood in Developing Countries: Selected Studies, Cynthia B. Lloyd, Jere R. Behrman, Nelly P. Stromquist, and Barney Cohen (eds.). Washington, DC: The National Academies Press.

Population Council. 2011. "The Adolescent Experience In-depth: Using Data to Identify and Reach the Most Vulnerable Young People," http://www. popcouncil.org/publications/serialsbriefs/AdolExplnDepth.asp. Accessed on May 27, 2011.

Santhya, K.G. and Shireen Jejeebhoy. 2003. "Sexual and reproductive health needs of married adolescent girls," Economic and Political Weekly 38(41): 4370-4377.

Santhya, K.G., Nicole Haberland, and Ajay Kumar Singh. 2006. "She only knew when the garland was put around her neck': Findings from an exploratory study on early marriage in Rajasthan." New Delhi: Population Council.

Santhya, K.G. and Shireen J. Jejeebhoy. 2007. "Early marriage and HIVIAIDS: Risk factors among young women in India," Economic and Political Weekly 42(14): 1291-1297.

Suran, Luciana, Sajeda Amin, Lopita Huq, and Kobita Chowdury. 2004. "Does dowry improve life for brides? A test of the bequest theory of dowry in rural Bangladesh." Policy Research Division Working Paper no. 195. New York: Population Council.

\section{Donors}

In recent years, donors have included: Department for International Development (UK), Ford Foundation, Bill \& Melinda Gates Foundation, Libra Foundation, The John D. and Catherine T. MacArthur Foundation, Rapidan Foundation, Turner Foundation, United Nations Children's Fund (UNICEF), United Nations Population Fund (UNFPA), United States Agency for International Development (USAID), and World Health Organization.

\section{(2 Population Council}

The Population Council changes the way the world thinks about critical health and development issues. We seek to understand the causes and consequences of gender inequality and the disparities in opportunity that arise during adolescence. We provide the evidence for better on-theground programs and policies that ensure successful and productive transitions to adulthood in developing countries. www.popcouncil.org

(c) 2011 The Population Council, Inc. 